\title{
Decolonising the Chagos Islands?
}

\author{
Jobn Reynolds ${ }^{\dagger}$
}

November 2019

Volume 2, Nigerian Yearbook of International Law

Portuguese 'discovery', French colonisation and British treaty dealings. Plantation and extraction. Racial capitalism and slave labour. Coercion and partition. Imperial alliance and militarisation. Displacement and exile. The story of the Chagos archipelago is a familiar one in the history of international law and relations between peoples. It is indicative of international law's complicity in European oppression and dispossession of colonised peoples and places. Yet while much of the machinations of colonial rule were spannered - at least nominally in the form of sovereignty-as-independence - by the national liberation movements of the $20^{\text {th }}$ century, the Chagos travesty persists into our $21^{\text {st }}$ century colonial present. Britain's refusal to let go of the small group of faraway islands serves as a contradictory symbol of both its self-deluding pretensions of empire on one hand, and its selfabasing servitude to United States imperialism on the other. It reminds us that colonialism is still very much with us, and that self-determination remains contingent. International law's ode to sovereign equality and territorial integrity is as much about concealing its own colonial foundations as it is about delivering on a promise of liberation.

In February 2019, the International Court of Justice (ICJ) issued an advisory opinion to confirm in law what we knew already as a matter of social and political and material reality: the British state had wrongfully kept control of the Chagos islands after Mauritius asserted its independence, and the process of decolonisation there is not yet complete. The core finding of the Court was that that Britain 'has an obligation to bring to an end its administration of the Chagos Archipelago as rapidly as possible'. ${ }^{1}$ On the face of it, this is a solid confirmation of international law's belated but definitive prohibition of colonialism. And yet we can also read the judgment as ringing somewhat hollow.

1960 was the high-water mark of formal decolonisation, before the swift tightening of 'the grip of neo-colonialism' ${ }^{2}$ and the restructured economic subjugation of the Third World. That year, 468 long years after Columbus claimed the island of Guanahani for the Spanish royals and set in chain a sequence of events

† Department of Law, National University of Ireland, Maynooth.

${ }^{1}$ ICJ, Legal Consequences of the Separation of the Chagos Archipelago from Mauritius in 1965, Advisory Opinion (25 February 2019) para. 182.

${ }^{2}$ Kwame Nkrumah, Neo-Colonialism: The Last Stage of Imperialism (Thomas Nelson \& Sons, 1965) x. 
whereby the veins of multiple continents were cut open and 'transmuted into European capital' ${ }^{3}$, the UN General Assembly passed Resolution 1514. Colonialism 'in all its forms and manifestations' (bar the small matter of settler colonies that had reconstituted themselves as sovereign states) was prohibited. Any attempt at the partial or total disruption of the national unity and the territorial integrity of any country was deemed incompatible with the purposes and principles of the UN Charter. Seventeen newly independent states joined the UN in 1960 and the Third World bloc became the majority in the General Assembly.

'Existing colonies may linger on', Nkrumah wrote in 1965, 'but no new colonies will be created'. ${ }^{4}$ Fading empires like Britain - and newer imperial powers like the US - were all too conscious of this. That same year, the British government orchestrated a way to carve a lingering colony out of the existing-but-not-for-toomuch-longer colony of Mauritius. By this time, the idea of territorial and military bases in relatively unpopulated areas was particularly appealing to Western powers. The "strategic island concept" being pursued by the US in particular sought to locate uninhabited island bases as a way to bypass rising anti-imperial sentiment around the globe. The potential of Chagos was clear: military planners would be 'thrilled at the idea of a base with no civilian population within almost 500 miles', and indeed 'planning between the British and U.S. governments had been underway since at least 1964'. ${ }^{5}$ Britain's task was, so to speak, to make Chagos terra nullius again. This would involve removing the Chagossians - Creole-speaking people descended from African slaves and indentured labourers - who had been inhabiting the islands for 200 years.

Through coercive means, the British government imposed the Lancaster House "agreement" on leaders of the Mauritius Council of Ministers to partition the colony and excise the Chagos archipelago as part of a newly constructed 'British Indian Ocean Territory' in 1965. No more than four days later, the Colonial Office sent instructions to the administration of this new territory stating that 'contingency planning for evacuation of existing population...should begin at once $^{6}$. In the lead-up to Mauritian independence in 1968, Britain began displacing the Chagossians from their archipelago: preventing those who travelled from returning, and forcibly removing others. Archive documentation has shown that the Foreign Office consistently lied about this during these years. For fear of being called out by the Committee of Twenty-Four (the UN Special Committee on Decolonisation), legal advisor Anthony Aust recommended that British officials 'maintain the fiction that the inhabitants of Chagos are not a permanent or semi-

\footnotetext{
${ }^{3}$ Eduardo Galeano, The Open Veins of Latin America: Five Centuries of the Pillage of a Continent (Monthly Review Press, 1973) 2.

${ }^{4}$ Kwame Nkrumah, Neo-Colonialism: The Last Stage of Imperialism (Thomas Nelson \& Sons, 1965) ix.

${ }^{5}$ David Vine, Island of Shame: The Secret History of the U.S. Military Base on Diego Garcia (Princeton University Press, 2009) 90.

${ }^{6}$ U.K. Trial Bundle (litigation documents) 4-132, Sheridans Solicitors, London, cited in Vine (2009), ibid.
} 
permanent population' but rather itinerant workers with no connection to the islands. ${ }^{7}$ Diplomatic correspondence from August 1966 is revealing of the attitudes prevalent in the colonial view of Chagos and its people. Paul Gore-Booth, Permanent Under-Secretary of State in the Foreign Office wrote: 'We must surely be very tough about this. The object of the exercise was to get some rocks which will remain ours; there will be no indigenous population except seagulls who have not yet got a Committee (the Status of Women does not cover the rights of Birds).' His colleague Denis Greenhill added: 'Unfortunately along with the birds go some few Tarzans or Men Fridays whose origins are obscure, and who are being hopefully wished on to Mauritius etc. When this has been done I agree we must be very tough'.

In December 1966, Britain leased the largest of the Chagos islands, Diego Garcia, to the US for the establishment of a naval and military base. International law facilitated this in an international treaty between the two, ${ }^{9}$ under which sovereignty over the territory was retained by Britain but competence for its administration was transferred to the US. There was no direct payment for the lease; instead the US contributed to the administrative costs of establishing the new colonial territory ('diplomatic legalese for the costs of deporting the Chagossians, buying out the plantation owners, and paying off Mauritius and the Seychelles ${ }^{10}$ ) and gave Britain a discount on the Polaris nuclear submarine ballistic missile system. The Chagossians were entirely absent from these arrangements, and the assumption underlying the agreement was that they would be entirely absent from the archipelago. Construction of the military base began in 1971, at which time forced expulsions ramped up, and between 1971 and 1973 the remaining inhabitants were put onto cargo ships and deported to Mauritius and the Seychelles. Just before the final deportations, 'British agents and U.S. troops on Diego Garcia herded the Chagossians' pet dogs into sealed sheds and gassed and burned them in front of their traumatized owners'. ${ }^{11}$

Since then, all human and economic activity in the Chagos archipelago has been concentrated in the military facilities on Diego Garcia. There has been no functioning agriculture on the islands. The Chagossians remain exiled but have continued a campaign to return. They plan to re-establish their lives and livelihoods there through fishing and coconut copra production. In recent years, much of the energy of this struggle has been supported by litigation - for return of the

7 Anthony Aust, 'Immigration Legislation for BIOT', Memorandum, 16 January 1970, quoted in Vine (2009) 92.

8 Foreign Office confidential memo ZD4/56, 'British Indian Ocean Territory', 24 August 1966, cited in R (on the application of Bancoult) v. Secretary of State for Foreign \& Commonwealth Affairs Rev 1 [2006] EWHC 1038 (Admin), Judgment, 11 May 2006, para. 27.

${ }_{9}^{9}$ Agreement Concerning the Availability for Defence Purposes of the British Indian Ocean Territory, 30

December 1966.

${ }_{10}^{10}$ Vine (2009) 87.

11 Vine (2009) 1. 
Chagossians, and for the archipelago to be reunified with Mauritius. In 2000, the High Court in Britain ruled that the 1965 colonial ordinance used as the basis to deport the islanders was unlawful. Instead of complying with the judgement and allowing them to return, Tony Blair's government issued an Order-in-Council to explicitly bar the Chagossians from re-inhabiting the archipelago. This was again challenged in the courts, but this time ultimately approved in 2008 by the House of Lords. ${ }^{12}$ In 2012, the European Court of Human Rights also rejected a case brought by 1,786 Chagossians against Britain as inadmissible; the Court felt it did not have jurisdiction over a colonial territory to which Britain had not actively extended its European human rights law obligations. ${ }^{13}$ So the Chagossians and Mauritius looked to international courts beyond the national and regional domain of the colonial power.

In 2015, an arbitral tribunal of the Permanent Court of Arbitration ruled that the Chagos 'Marine Protected Area' which Britain had created in 2010 (publicly for conservation purposes but actually, in confidence, 'to assure that U.S. interests were safeguarded', 'to get through the various Chagossian lobbies', to 'put paid to resettlement claims' and make it 'difficult, if not impossible' for the Chagossians to return ${ }^{14}$ ) violates international law. ${ }^{15}$ It also ruled that Britain does have obligations towards Mauritius over the return of the archipelago, but only when it is no longer needed for defence purposes. This left enough space for the British Foreign Office to announce in 2016 that 'the government has decided against resettlement of the Chagossian people' - on grounds that it would be expensive and impractical - and that, with the initial 50-year lease period expiring in December 2016, the agreement with the US would be extended: 'In an increasingly dangerous world, the defence facility is used by us and our allies to combat some of the most difficult problems of the 21 st century including terrorism, international criminality, instability and piracy. I can today confirm that the UK continues to welcome the US presence, and that the agreements will

\footnotetext{
$12 \mathrm{R}$ (on the application of Bancoult) v. Secretary of State for Foreign \& Commonwealth [2008] UKHL 61, Judgment, 22 October 2008. See further Stephen Allen, The Chagos Islanders and International Law (Hart, 2014), Chapter 1.

${ }_{13}$ Chagos Islanders v. UK, European Court of Human Rights, Application No. 35622/04, Fourth Section Decision, 11 December 2012. See further Allen (2014), Chapter 2.

14 'HMG Floats Proposal for Marin Reserve Covering the Chagos Archipelago (British Indian Ocean Reserve)', Confidential Cable from US Embassy in London, REF: 08LONDON2667, 5 May 2009, published by Wikileaks and The Guardian, 2 December 2010. Colin Roberts, the British Foreign and Commonwealth Office Director for Overseas Territories is quoted in the cable: "We do not regret the removal of the population," since removal was necessary for the BIOT to fulfill its strategic purpose'. The US State Department author of the cable concludes that: 'Establishing a marine reserve might, indeed, as the FCO's Roberts stated, be the most effective long-term way to prevent any of the Chagos Islands' former inhabitants or their descendants from resettling in the BIOT.'

15 Permanent Court of Arbitration, Arbitral Tribunal Constituted under Annex VII of the United Nations Convention on the Law of the Sea, In the Matter of the Chagos Marine Protected Area: Mauritius v. the United Kingdom, Award of 18 March 2015. While finding in favour of Mauritius on this point of the incompatibility of the Marine Protected Area with British obligations under the UN Convention on the Law of the Sea (UNCLOS), the Arbitral Tribunal at the same ruled that Mauritius's claim to sovereignty over the Chagos archipelago was not something for the Tribunal to consider under UNCLOS.
} 
continue as they stand until 30 December 2036. ${ }^{16}$ Within a month of this extension kicking in, the African Union resolved to work to ensure 'the completion of the decolonization of the Republic of Mauritius'. ${ }^{17}$

And so, to the ICJ. In June 2017, after many iterations over the years of UN General Assembly, African Union and Non-Aligned Movement condemnation of British policy on Chagos, the General Assembly requested the Court's advisory opinion on the questions of: (i) whether the process of decolonisation of Mauritius was lawfully completed when Mauritius gained independence in 1968 following the separation of the Chagos Archipelago from Mauritius; and (ii) what the consequences are under international law arising from the continued administration of the Chagos Archipelago by Britain, including with respect to the resettlement of the Chagossians. ${ }^{18}$ The resolution was carried by the global South, with many European countries opting to abstain and a smallish collection of states voting with Britain against the move.

The history of international law is a history of unequal relations. In the Chagos proceedings at the ICJ, a number of Third World states made representations about the unequal nature of treaties imposed by colonial powers on representatives of the colony prior to independence. They noted the structural biases in favour of colonial states as a persistent feature of international treaties. While this was hardwired into international law historically, the argument is that this was no longer valid by the time of the Vienna Convention on the Law of Treaties in the late 1960s: 'one could hardly deny that treaties dictated by the stronger to the weaker party would qualify as unequal treaties. This idea of inequality has been recognized and has played a crucial role in the development of international law. ${ }^{19}$

In 1964, the Committee of Twenty-Four made clear its opinion that the constitutional arrangements in Mauritius 'do not allow the representatives of the people to exercise real legislative or executive powers, and that authority is nearly all concentrated in the hands of the United Kingdom Government and its representatives. ${ }^{20}$ The advisory opinion narrates the story of the Lancaster House agreement from there. The Colonial Office and the Governor of Mauritius informed the native Council of Ministers and the Premier of their proposal to

${ }^{16}$ Foreign and Commonwealth Office, 'Update on the British Indian Ocean Territory: Written statement HCWS260', 16 November 2016. The statement was delivered in parliament by Alan Duncan, Minister of State for Foreign and Commonwealth Affairs.

17 African Union, 'Resolution on Chagos Archipelago', Assembly/AU/Res.1 (XXVIII), 30 January 2017.

18 General Assembly Resolution 71/292, UN Doc. A/RES/71/292, 22 June 2017.

${ }^{19}$ Legal Consequences of the Separation of the Chagos Archipelago from Mauritius in 1965, Statement by Thailand, Verbatim Record, 6 September 2018, para. 10.

20 'Report of the Special Committee on the Situation with regard to the Implementation of the Declaration on the Granting of Independence to Colonial Countries and Peoples', UN Doc. A/5800/Rev.1, 1964-1965, p. 352, para. 154 
constitutionally sever the Chagos archipelago from the rest of Mauritius. The Council of Ministers opposed this. Britain's Foreign Secretary and Defence Secretary said that if Mauritius would not agree, they would have to implement a 'forcible detachment'. The counter-offer made by the Premier of Mauritius was that Britain should first concede independence to Mauritius, including sovereignty over Chagos, and then the Mauritian Government could negotiate with the Britain and the US on the question of Diego Garcia. The Brits were not open to this. In planning a meeting with the Premier of Mauritius, the aim of the British Prime Minister was to: 'frighten him with hope: hope that he might get independence; Fright lest he might not unless he is sensible about the detachment of the Chagos Archipelago. ${ }^{21}$ Judge Robinson cites a subsequent comment from the Premier: 'There was a noose around my neck. I could not say no. I had to say yes, otherwise the [noose] could have tightened. ${ }^{22}$

And so it was. Amputating Chagos was the price of Mauritian independence. The ICJ, while not casting it explicitly in terms of coercion or duress, concluded that this was illegitimate: 'heightened scrutiny should be given to the issue of consent in a situation where a part of a non-self-governing territory is separated to create a new colony' - and in this specific situation 'detachment was not based on the free and genuine expression of the will of the people concerned. ${ }^{23}$

On that foundation, the Court makes a series of short, snappy steps from the applicable law to its main findings: the right of peoples to self-determination was established as a normative principle of customary international law by 1965; state practice and opinio juris at the time confirmed that respect for the territorial integrity of a non self-self-governing territory was a key element of selfdetermination; the General Assembly has important functions in overseeing the implementation of self-determination in the context of decolonisation; because the Chagos archipelago was an integral part of the non-self-governing territory of Mauritius and was illegitimately separated in 1965, the process of decolonisation of Mauritius was not lawfully complete when the rest of the territory became independent in 1968; Britain's continuing administration of the territory is an internationally wrongful act which must be ended as quickly as possible, and all members states must cooperate with the UN to complete the decolonisation of Mauritius. ${ }^{24}$

This is all well and good in terms of the Court's baseline commitment to self-determination and the upshot that the colonial protagonist here 'totally lost

\footnotetext{
${ }^{21}$ Legal Consequences of the Separation of the Chagos Archipelago, para. 105, quoting note from Private Secretary to Prime Minister Harold Wilson, 22 September 1965.

22 ICJ, Legal Consequences of the Separation of the Chagos Archipelago from Mauritius in 1965, Separate Opinion of Judge Robinson (25 February 2019) para. 93, citing Mauritius Legislative Assembly, Reply to PQ No. B/1141 (25 November 1980) p. 4223.

${ }^{23}$ Legal Consequences of the Separation of the Chagos Archipelago, para. 172.

${ }^{24}$ Legal Consequences of the Separation of the Chagos Archipelago, paras. 139-182.
} 
the case. There's no silver lining, ${ }^{25}$ The brevity of the opinion's reasoning on the substance and its lack of engagement with some of the arguments made in state submissions, however, leaves a sense of hollowness. It exposes the opinion to both doctrinal objections and deeper critique. On the question of whether selfdetermination was already a rule of customary international law by the period between 1965 and 1968, for example, it has been suggested that 'the Court completely fudges it' by making a 'plain assertion' unsupported by sufficient evidence of state practice or opinio juris. ${ }^{26}$ From a more critical perspective, the weight given in the first place to a traditional conception of customary international law highlights the very "nature and politics of "custom" as a continuing source of international law', which, with its twin requirements of attesting "state practice" and "opinio juris" has facilitated and advanced the imperial order. ${ }^{27}$ B.S. Chimni has illustrated that the historic role of customary international law 'has been to facilitate the functioning of global capitalist system by filling crucial gaps in the international legal system' - gaps relating to either short term interests of capitalist states or the systemic interests of the global capitalist system. ${ }^{28}$ While very definitively linking (or, some argue, 'shrinking' ${ }^{29}$ ) self-determination to decolonisation, the advisory opinion does little to advance the more radical, humane, "postmodern" conceptualisation of customary international law that Chimni suggests. ${ }^{30}$ The African Union submissions also gave the court the opportunity to (re)develop in the interests of the Third World the doctrine of specially-affected states ("concerned states") as an essential component of determining customary international law: 'There is no doubt that those who are the concerned States in the present proceeding are, first and foremost, the African States and then those states that have been victims of colonialism (most of whom are part of the Non-Aligned Movement), ${ }^{31}$ But again the Court sidesteps this opportunity.

Ultimately, the advisory opinion pushes up against the limitations imposed by international law's state-centricity. The Chagossians themselves remain somewhat peripheral. A few of the separate opinions do make the point that the Court does not do enough to account for their human and material experience.

\footnotetext{
${ }^{25}$ Marko Milanovic, 'ICJ Delivers Chagos Opinion, UK Loses Badly', EJIL: Talk!, 25 February 2019.

26 Milanovic (2019), ibid.

${ }^{27}$ Kanad Bagchi, 'Imperialism, International Law and the Chagos Islands: Reflections on Legal Consequences of the Separation of the Chagos Archipelago', Völkerrechtsblog, 1 March 2019.

28 B.S. Chimni, 'Customary International Law: A Third World Perspective' (2018) 112:1 American Journal of International Law 1-46.

${ }^{29}$ Jan Klabbers, 'Shrinking Self-determination: The Chagos Opinion of the International Court of Justice' 8:2 ESIL Reflections (27 March 2019).

${ }^{30}$ For explication, see Chimni (2018) 36-43. In a passage on opinio juris in this analysis, Chimni draws on (and critiques) Judge Cançado Trindade, who (characteristically) makes clear in his Separate Opinion that he wanted to go further than the Court on this aspect of the Chagos case.

31 Legal Consequences of the Separation of the Chagos Archipelago from Mauritius in 1965, Written Comments of the African Union on other Written Statements, 15 May 2018. See also Kevin Jon Heller, 'Specially-Affected States and the Formation of Custom' (2018) 112:2 American Journal of International Law 191-243.
} 
And Judges Robinson and Cançado Trindade both write the testimony of Liseby Elysé into their opinions, giving voice to her personal experience as illustrative of the voice of the colonised and the plight of the Chagossians. ${ }^{32}$ This is necessarily an individual testimony, however, not the type of 'powerful collective representations' which have solicited powerful support for the Chagossian cause but which do not fit the 'more positivistic understanding of history imposed by formal concepts of legal evidence. ${ }^{33}$

Beyond this, the core focus of the advisory opinion, by virtue of international law's traditions and structures, is overwhelmingly on Mauritius's territorial sovereignty rather than the Chagossians' right to return. Even with the restoration of Mauritian sovereignty over the archipelago and the completion of the process of decolonisation from the perspective of international law as the Court sees it, the fate of the people and ecology of Chagos remains contingent on the priorities of (and pressures on) the state of Mauritius. The substantive findings section of the Court's advisory opinion devotes just a single sentence to the uprooted Chagossians. ${ }^{34}$ It casts their situation as a human rights issue which should be considered in the General Assembly's work subsequent to the advisory opinion, but which is beyond the scope of the ICJ itself. Cançado Trindade's discussion of the 1955 Bandung conference ${ }^{35}$ - and his reference to the collection of essays that a substantial number of TWAIL-oriented scholars contributed to ${ }^{36}$ is a welcome acknowledgment of the role that the Third World played in influencing international law and the UN at the time. But it is also emblematic of the deficiencies of international law - even that shaped by Bandung - in being able to adequately address the Chagos situation. The pluralism of Bandung and the Non-Aligned Movement ultimately meant that in the distillation of the "spirit of Bandung" into doctrinal positions, the more radical strands of Third Worldist thought and praxis were filtered out, and the core focus was a statist one preoccupied with national political independence and territorial sovereignty.

In April 2019, the British Foreign Office responded to the ICJ's findings with a confident, if unsubstantiated, rebuttal: 'The Government has considered the content of the Opinion carefully, however we do not share the Court's approach...we have no doubt about our sovereignty over the Chagos

32 ICJ, Legal Consequences of the Separation of the Chagos Archipelago from Mauritius in 1965, Separate Opinion of Judge Robinson (25 February 2019), para. 104; Separate Opinion of Judge Cançado Trindade, para. 219.

${ }^{33}$ Laura Jeffery, 'How a Plantation became Paradise: Changing Representations of the Homeland among Displaced Chagos Islanders' (2007) 13:4 Journal of the Royal Anthropological Institute 951-968.

${ }^{34}$ Legal Consequences of the Separation of the Chagos Archipelago, para. 181.

35 ICJ, Legal Consequences of the Separation of the Chagos Archipelago from Mauritius in 1965, Separate Opinion of Judge Cançado Trindade (25 February 2019) paras. 43-49.

36 Luis Eslava, Michael Fakhri and Vasuki Nesiah (eds.), Bandung, Global History, and International Law - Critical Pasts and Pending Futures (Cambridge University Press, 2017). 
Archipelago, ${ }^{37} \mathrm{~A}$ former empire remains happily ensconced in its global boardgame activities, with real-world consequences. Its statement to the UN General Assembly in May 2019 reveals a continuing belief in the validity of its own selfappointment as global police force: 'In this important part of the world, the joint United Kingdom and United States defence facility on the British Indian Ocean Territory plays a vital role in our efforts to keep our allies and friends, including Mauritius, in the region, and beyond, safe and secure. ${ }^{38}$ The General Assembly voted that day to welcome the ICJ advisory opinion and demand that Britain 'withdraw its colonial administration unconditionally within a period of no more than six months'. ${ }^{39} 116$ member states voted in favour of the resolution, with just six voting against. Five of them - Britain, the US, Israel, Australia and Hungary form a type of settler-colonial/white-nationalist alliance that is reminiscent of the 'unholy alliance between Portuguese colonialism, South African racism and Israeli imperialism' which the General Assembly used to condemn in the 1970 s. $^{40}$ (The sixth, the Maldives, defends its vote as seeking to protect itself against a potential reduction in its Exclusive Economic Zone in the Indian Ocean, which could occur if sovereignty over Chagos was returned to Mauritius before pending claims over the maritime boundaries between the two states are resolved). Six months later, in November 2019, Britain had not withdrawn its colonial administration, and was described by commentators as 'a rogue state'. ${ }^{41}$

There has been much talk in recent years of the imperatives of decolonising - "decolonising the university", "decolonising dialectics", "decolonising international law", and so on. This work of 'decolonising' as reimagining or restructuring is vital - if not always rooted in material struggles in the colonised world, and perhaps sometimes better not labelled as decolonisation. In sites where colonial rule and occupation continues, or where Indigenous peoples struggle against settler colonial structures and suffocation, decolonisation is not a metaphor. ${ }^{42}$ In 1965, while the fate of the Chagos archipelago and its people was being altered by imperial coercion, across the continent Amílcar Cabral was appealing to his revolutionary party (under Portuguese rule in Guinea and Cape Verde) to be wary of seeing decolonisation as simply the liberation of the mind:

${ }^{37}$ Foreign and Commonwealth Office, 'British Indian Ocean Territory: Written statement - HCWS1528', 30 April 2019.

${ }^{38}$ Foreign and Commonwealth Office, 'Statement and explanation of vote on the resolution on the British Indian Ocean Territories by Ambassador Karen Pierce, UK Permanent Representative to the UN', 22 May 2019.

39 UN General Assembly Resolution 73/295, UN Doc. A/RES/73/295, 22 May 2019, para. 3.

40 UN General Assembly Resolution 3151 (XXVIII), 14 December 1973, para. (G)5.

${ }^{41}$ Rachael Kennedy, 'UK labelled 'rogue state' after missing UN deadline to hand Chagos Islands back to Mauritius', EuroNews, 22 November 2019.

42 Eve Tuck and K. Wayne Yang, 'Decolonization is Not a Metaphor' (2012) 1:1 Decolonization: Indigeneity, Education \& Society 1-40. 
'Always bear in mind that the people are not fighting for ideas, for the things in anyone's head. They are fighting to win material benefits, to live better and in peace, to see their lives go forward, to guarantee the future of their children. ${ }^{43}$ For the Chagossians, these material benefits and these futures are wrapped up in their bond with the lands and waters of the archipelago. Decolonisation is inseparable from their right to return. The ICJ advisory opinion's deflection of the question of their return is telling. The opinion fails to factor that - just as their removal was essential to the latest stage of imperialism in the archipelago - their return is intrinsic to the process of decolonisation, not an ancillary element to be negotiated.

The scale and significance of the US war base operation on Diego Garcia since its establishment cannot be underestimated: billions invested in the largest build-up of any location after the Vietnam War; lucrative contracts for private military contractors; nuclear-capable bombers and likely nuclear weapons storage; NASA facilities and electro-optical deep space surveillance systems; pivotal wartime functions in the first Gulf War, the war on Afghanistan and the 2003 invasion of Iraq; site of rendition flight stop-offs, clandestine "black site" detentions and possibly 'secret prison ships' in the waters of the archipelago. ${ }^{44}$ It is 'the single most important military facility we've got...the base from which we control half of Africa and the southern side of Asia', according to US military specialists. ${ }^{45}$ Since the ICJ advisory opinion came down, the realpolitik pragmatism espoused in establishment circles has returned to the fore. Channelling the logic of "there is no alternative", this position assumes that the Diego Garcia base will remain and that Mauritius will acquiesce. As one former diplomat puts it: 'Eventually, the issue of sovereignty will have to be finessed by agreements that allow continuation of the military base at Diego Garcia with guarantees that Mauritius will retain sovereignty over the Chagos archipelago. Mauritius will agree to lease out the island for a long period to the U.S. for maintaining the military base. ${ }^{46}$ As it stands, the US position remains that, for security reasons, the Chagos archipelago must not be inhabited. The structures of the international economic order ensure that unequal relations continue, and that global North powers can get much of what they want by incentive and coercion.

Cabral's warnings of the dangers of neo-colonialism are prescient here. $\mathrm{He}$ conceptualises the liberation of a people in terms of 'the regaining of the historical personality of that people, its return to history through the destruction of the imperialist domination to which it was subjected...for us the basis of national liberation, whatever the formulas adopted on the level of international law, is the inalienable

43 Amílcar Cabral, 'Extracts from Party directive 1965', in Amílcar Cabral, Revolution in Guinea: An African People's Struggle (Stage 1, 1969) 70.

44 Vine (2009) 8-10.

45 Vine (2009) 10.

46 Pinak Ranjan Chakravarty, 'Decolonising the Chagos Archipelago', The Hindu, 4 June 2019. 
right of every people to have its own history'. Given 'the essential characteristics of the present world economy' and the 'experiences already gained in the field of anti-imperialist struggle', the principal struggle is against neo-colonialism. ${ }^{47}$ For Cabral, anti-colonialism must be an interruption of the colonial practices and structures that have been imposed. A process of decolonisation that leaves an imperial military base intact will remain incomplete, even if sovereignty is transferred from one state to another. In this sense, the struggle for the abolition of the Diego Garcia base and for the people's return to Chagos is part of a broader struggle to (re)make the world anew - a struggle to claim the future, to restore local economies and ecologies in place of global war-game capitalism. This will be a constant struggle. Decolonisation and social emancipation, as Galeano reminds us, must be built with convincing strategy and clenched teeth: 'after all, if the future came on a platter, it would not be of this world. ${ }^{, 48}$

47 Amílcar Cabral, 'The Weapon of Theory', Address delivered to the first Tricontinental Conference of the Peoples of Asia, Africa and Latin America, Havana, January 1966. Emphasis added.

48 Galeano (1973) 77. 